\title{
Fire barrier based on expanded perlite composites
}

\author{
Robert Kusiorowski ${ }^{1}$, Jerzy Witek ${ }^{2}$, Izabela Majchrowicz ${ }^{3}$, Andrzej Kleta ${ }^{4}$, Anna Jirsa-Ociepa ${ }^{5}$ \\ 1, 2, ${ }^{3}$ Eukasiewicz Research Network, Institute of Ceramics and Building Materials, \\ Refractory Materials Division in Gliwice, Gliwice, Poland \\ ${ }^{4,}{ }^{5}$ Kadet Izolacje Ogniotrwate Andrzej Kleta, Gliwice, Poland \\ E-mail: ${ }^{1}$ r.kusiorowski@icimb.pl (correspondingauthor)
}

\begin{abstract}
Decreased strength of building materials as a result of flame impingement (e.g. during a fire) is one of major threats in the construction branch. For these reasons, the effectiveness of fire safety systems in various kinds of facilities or structures is extremely important. One of the determinants of this effectiveness is so-called fire insulation, i.e. time expressed in minutes after which an increase in the temperature of a protected structure or facility exceeds a certain admissible value $\left(140{ }^{\circ} \mathrm{C}\right)$. The results of investigations presented in the article concern the determination of the effect of various mineral binders used in the manufacture of insulation boards from expanded perlite on fire resistance and, in consequence, on extending the time of fire insulation in the conditions of cellulose and hydrocarbon fire. The conducted research has revealed that the fire resistance of perlite products can be modelled by selecting adequate mineral binders, with respect to specific applications and economic considerations. Insulation boards based on expanded perlite - depending on the binder used - were characterized by a fire insulation ranging (with a board thickness of $50 \mathrm{~mm}$ ) from 50 to 100 minutes in the conditions of cellulose fire and from 20 to 30 minutes in the conditions of hydrocarbon fire.
\end{abstract}

Keywords: expanded perlite, thermal insulation, fire barrier composite, mineral binders.

\section{Introduction}

The use of materials for thermal insulation is directly related to the influence of high or low temperatures. One of the advantages of heat-insulating building materials is their relatively good resistance to high temperature, which results from their low thermal conductivity. High temperature can influence an insulating material through conductivity in the form of direct contact with a heated-up construction element or through radiation exchange, if the source of heat is located within a certain distance. Direct exposure to fire is also possible.

Based on PN-EN 13501-1 standard all building products should be classified according to fire resistance. This classification includes seven classes of materials in terms of their reaction to fire (classes: A1, A2, B, C, D, E, F) with additional criteria, which take into account smoke release and the occurrence of flaming droplets (Table 1). The safest building materials are the ones belonging to class A1, followed by classes A2 and B. Products marked as class C, D, $\mathrm{E}$ and $\mathrm{F}$ can result in flashover, that is, sudden, explosive propagation of fire, followed by a temperature surge. For this reason, application of C, D, E or F class products should be limited.

Fire properties of building products and materials used to furnish interiors are extremely important, in particular during the first stage of a fire. When properly selected, such materials can ensure people's safety, enabling their effective evacuation; they can also lower the speed of fire propagation, and, in consequence, reduce the size of damage related to the destructive effect of fire. A fire in a building can propagate at a very fast pace, causing substantial material losses and posing a threat to people staying inside. For these reasons, passive fire protection becomes a matter of increasing significance. It involves enhancing the safety and minimizing losses in case of fire.

Although each uncontrolled process of flammable materials combustion is referred to as a fire, its size and nature depend on many factors - the type of flammable materials, ventilation, suppression agents etc. So-called temperature curves presenting temperature changes versus time have been determined so as to have a reference point (Figure 1). There are among others two types of fires - cellulosic and hydrocarbon ones (Gardelle, Duquesne, Vandereeckem, \& Bourbigot, 2014; Wiatr, 2012):

- cellulosic fire is the most frequent one; it affects commercial buildings and infrastructure; flammable materials include materials used on a daily basis - paper, wood, textiles. In this kind of fire, the temperature of the system grows slowly, reaching $900{ }^{\circ} \mathrm{C}$ approximately after an hour. However, the temperature of $500{ }^{\circ} \mathrm{C}$

(C) 2019 Authors. Published by VGTU Press. This is an open-access article distributed under the terms of the Creative Commons Attribution (http://creativecommons.org/licenses/by/4.0/) License, which permits unrestricted use, distribution, and reproduction in any medium, provided the original author and source are credited. 
is reached already 5 minutes after an accidental initiation of a fire. Finally, the temperature can reach a level of ca $1100{ }^{\circ} \mathrm{C}$;

- hydrocarbon fire is much more dangerous and is mainly related to big industrial installations; it usually breaks out on drilling platforms, in petrochemical plants, gas fittings, and the fuels used are flammable oils, gases and chemicals. This type of fire is characterized by an extremely fast temperature rise - within merely a few minutes the temperature in the system reaches approximately $1000^{\circ} \mathrm{C}$. Fire propagates instantly, and the flame is very strong and turbulent.

Table 1. Fire classification of building materials

\begin{tabular}{|c|l|l|l|}
\hline Class & \multicolumn{1}{|c|}{ Properties } & \multicolumn{1}{|c|}{ Flashover risk } & \multicolumn{1}{c|}{ Examples of products } \\
\hline A1 & non-flammable & $\begin{array}{l}\text { no flashover, minimal value of } \\
\text { combustion heat }\end{array}$ & $\begin{array}{l}\text { concrete, steel, rock wool, } \\
\text { glass wool }\end{array}$ \\
\hline A2 & non-flammable & $\begin{array}{l}\text { no flashover, low value of com- } \\
\text { bustion heat }\end{array}$ & $\begin{array}{l}\text { drywalls, high-density min- } \\
\text { eral wool }\end{array}$ \\
\hline B & $\begin{array}{l}\text { ignitability with a small flame for } 60 \mathrm{~s} \\
\text { Fs }<150 \mathrm{~mm}, \text { limited participation in a fire }\end{array}$ & no flashover & hard PVC \\
\hline C & $\begin{array}{l}\text { ignitability with a small flame for } 60 \mathrm{~s} \\
\text { Fs }<150 \mathrm{~mm}, \text { limited but noticeable participa- } \\
\text { tion in a fire }\end{array}$ & $\begin{array}{l}10 \text { minutes with a heat flux of } \\
300 \mathrm{~kW}\end{array}$ & $\begin{array}{l}\text { some polyurethane foams, } \\
\text { drywall with wallpaper }\end{array}$ \\
\hline D & $\begin{array}{l}\text { ignitability with a small flame for } 60 \mathrm{~s} \\
\text { Fs }<150 \mathrm{~mm}, \text { significant participation in a fire }\end{array}$ & $\begin{array}{l}\text { flashover not earlier than after } \\
2 \text { min with a heat flux of } 100 \mathrm{~kW}\end{array}$ & $\begin{array}{l}\text { most polyurethane foams, } \\
\text { unimpregnated wood }\end{array}$ \\
\hline E & $\begin{array}{l}\text { ignitability with a small flame for 20 } \mathrm{s} \\
\text { Fs }<150 \mathrm{~mm} \text {, very high participation in a fire }\end{array}$ & $\begin{array}{l}\text { flashover not earlier than after } \\
2 \text { min with a heat flux of } 100 \mathrm{~kW}\end{array}$ & $\begin{array}{l}\text { foamed plastics characterized } \\
\text { by reduced flammability }\end{array}$ \\
\hline F & $\begin{array}{l}\text { very high participation in a fire or no require- } \\
\text { ments }\end{array}$ & $\begin{array}{l}\text { has not been tested or does not } \\
\text { fulfil any criteria }\end{array}$ & foamed plastics \\
\hline
\end{tabular}

Fs - flame propagation, w $\mathrm{mm}$.

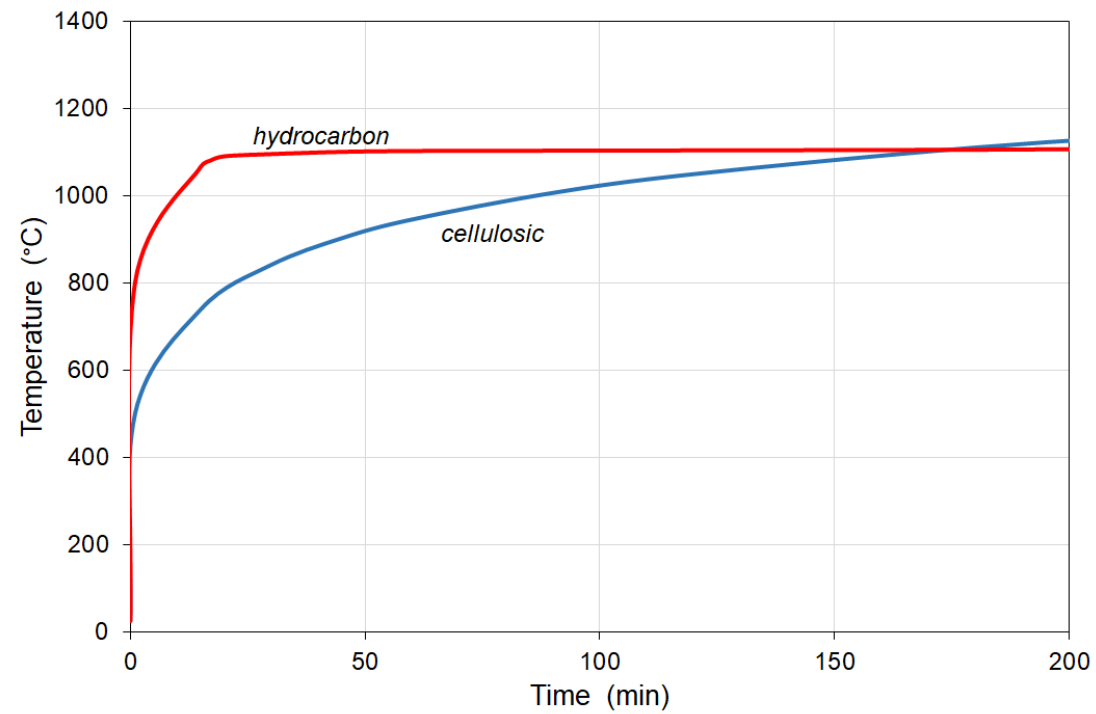

Figure 1. Model curves of temperature increase for cellulosic and hydrocarbon fires

From the point of view of fire tests for building materials, an important parameter is fire-resistance rating, which is defined as the ability of a building element to fulfil specific requirements under conditions simulating the spread of fire. The measure of fire resistance is a time, expressed in minutes, between the beginning of the fire and the moment 
when the building element fulfils one of the three limit criteria, i.e. load bearing (R), integrity (E) or insulation (I) (Borowy, 2013):

- Load bearing $(\mathrm{R})$ is a state in which the test element no longer fulfils its load bearing function due to mechanical destruction, loss of stability and the exceeding of the limit values of displacement or deformation.

- Integrity (E) is a state in which the test element no longer fulfils its separating function due to the appearance of flames on the unheated surface, cracks or gaps with dimensions exceeding the limit values which are penetrated by flames, gases, or a state in which the test element comes off the structure.

- Insulation (I) is a time, expressed in minutes, during which an element of the building under fire conditions ceases to fulfil the function of safe isolation due to the excessively high temperature of the unheated surface. On the market there are many heat-insulating materials - polystyrene foam, mineral or glass wool products. One of such materials is also expanded perlite. Perlite itself is metamorphic volcanic rock built of acidic volcanic enamel, which contains 2 to $5 \%$ of the volume of water trapped in solidified lava. In chemical terms, perlite is hydrated potassium-sodium aluminosilicate, containing mainly silica $\mathrm{SiO}_{2}(65 \div 75 \%)$ and alumina $\mathrm{Al}_{2} \mathrm{O}_{3}(10 \div 18 \%)$, as well as sodium and potassium oxides $\mathrm{K}_{2} \mathrm{O}+\mathrm{Na}_{2} \mathrm{O}(6 \div 9 \%)$, magnesium and calcium oxides $\mathrm{MgO}+\mathrm{CaO}(2 \div 6 \%)$ and iron oxides $\mathrm{Fe}_{2} \mathrm{O}_{3}$ $(1 \div 5 \%)$. The chemical composition of perlite is subject to slight changes, depending on the source of its origin (Burkowicz, 2016; Żelazowska, Pichniarczyk, \& Najduchowska, 2014).

When a perlite material is heated to a temperature exceeding $850 \div 870{ }^{\circ} \mathrm{C}$, its grains swell, which is related to a sudden transition of water in the perlite structure into steam. This causes $10 \div 40$-fold increase of volume and reduction of the material's density - it is so-called process of expanding. The degree of expanding depends on the content of the particles of water trapped in perlite rock. The density of raw perlite ranges from 2.23 to $2.40 \mathrm{~g} / \mathrm{cm}^{3}$, whereas for expanded perlite it is merely $0.05 \div 0.15 \mathrm{~g} / \mathrm{cm}^{3}$. The process of expanding is irreversible and leads to the formation of irregularly shaped empty, glassy bubbles with air trapped inside the material. Due to the specific method of obtaining and the form of the material, expanded perlite is characterized by favourable insulating properties. Heat conductivity $\lambda$ for expanded perlite is $0.04 \div 0.06 \mathrm{~W} /(\mathrm{mK})$ (Burkowicz, 2016; Żelazowska, Pichniarczyk, \& Najduchowska, 2014). Perlite is being used in different areas such as construction materials (Demirboğa \& Gül, 2003; Sengul, Azizi, Karaosmanoglu, \& Ali Tassemir, 2011; Singh \& Garg, 1991), agriculture (Markoska, Lisichkov, Boev, \& Gulaboski, 2018), medical and chemical industry (Ghassabzadeh, Mohadespour, Torab-Mostaedi, Zaheri, Maragheh, \& Taheri, 2010; Sari, Tuzen, Citak, \& Soylak, 2007).

The investigations presented in the article were focused on determining the influence of various mineral binders used to bind insulating boards of expanded perlite, with the aim to increase their fire resistance by extending the insulation time under cellulosic or hydrocarbon fire conditions.

\section{Experimental}

Materials and methods

The subject of research were insulating boards having the dimensions of $800 \times 400 \times 50 \mathrm{~mm}^{3}$, produced by Kadet Izolacje Ogniotrwałe Andrzej Kleta, according to the technology developed within the framework of the Project entitled "Developing a technology and start-up of the production of innovative perlite products as well as heat and fire protection systems for selected facilities and building structures". For the needs of investigations, four batches of boards were manufactured and marked with letters A, B, C and D, according to the "know-how" of the plant; in the process of manufacture the identical parameters of process unit operations were applied, such as: the time of perlite mass components mixing, forming pressure and drying parameters. The factor which made the production technology different was the use of binders characterized by various molar fractions of alkaline substances. In variant $\mathrm{A}$ it was the highest; it decreased in subsequent variants $B$ and $C$ to reach the value of ca 0.2 in variant $D$.

\section{Methods}

The scope of research into four variants of perlite boards encompassed: (a) determining the physical properties of the boards, including: apparent density, open porosity, water absorption, compressive strength, thermal conductivity coefficient at selected temperatures, and microstructure. All the determinations were conducted in accordance with the standards and binding research procedures; (b) fire resistance tests, which were carried out at a special test stand with a silit kiln, in which the parameters of model temperature curves, consistent with the curves of temperature increase of cellulosic and hydrocarbon fires, were simulated.

Before commencing the tests, perlite boards were cut to the dimensions required by the determination and, next, dried in a laboratory drier at $105{ }^{\circ} \mathrm{C}$ for $8 \mathrm{~h}$. A selected board was also subjected to microstructure observations in a scanning electron microscope (SEM).

Apparent density was determined in two ways, both by the volumetric method as a ratio of sample mass after drying to its volume by dimensioning the sample with a digital caliper, and by the hydrostatic weighing method, using water as a working liquid. The second method, in which masses of the dried sample saturated with a liquid (the soaking method) and of the sample saturated with a liquid and weighed in the working liquid were determined, also allowed 
determining open porosity and absorbability of the material. Compressive strength tests were carried out for samples in the shape of cubes with a side of $50 \mathrm{~mm}$ on a hydraulic press. A sample having known dimensions was subjected to steadily increasing compressive loading until it was destroyed. Compressive strength was calculated from the maximum loading indicated when the sample was destroyed and from the surface of the area where the loading was applied.

Thermal conductivity was determined by the so-called hot-wire method in a parallel system, in accordance with PN-EN 993-15 standard. It is a dynamic measurement method, based on determining the increase of temperature versus time in a specific place and distance from the linear source of heat, fixed between two elements of the testing sample. The sample is heated in a kiln up to a specified temperature and, next, it is kept at this temperature. Further local heating is carried out by means of a hot wire with a thermocouple placed in the sample. A measure of the material's thermal conductivity is a rise in temperature versus time, measured from the moment when power is turned on. The investigations were conducted by means of an Netzsch TCT-426 thermal conductivity analyser. The microstructure of selected perlite boards was observed in a scanning electron microscope (Mira III, Tescan) equipped with an Energy Dispersive Spectroscopy (EDS) system with AZtec Auomated software (Oxford Instruments).

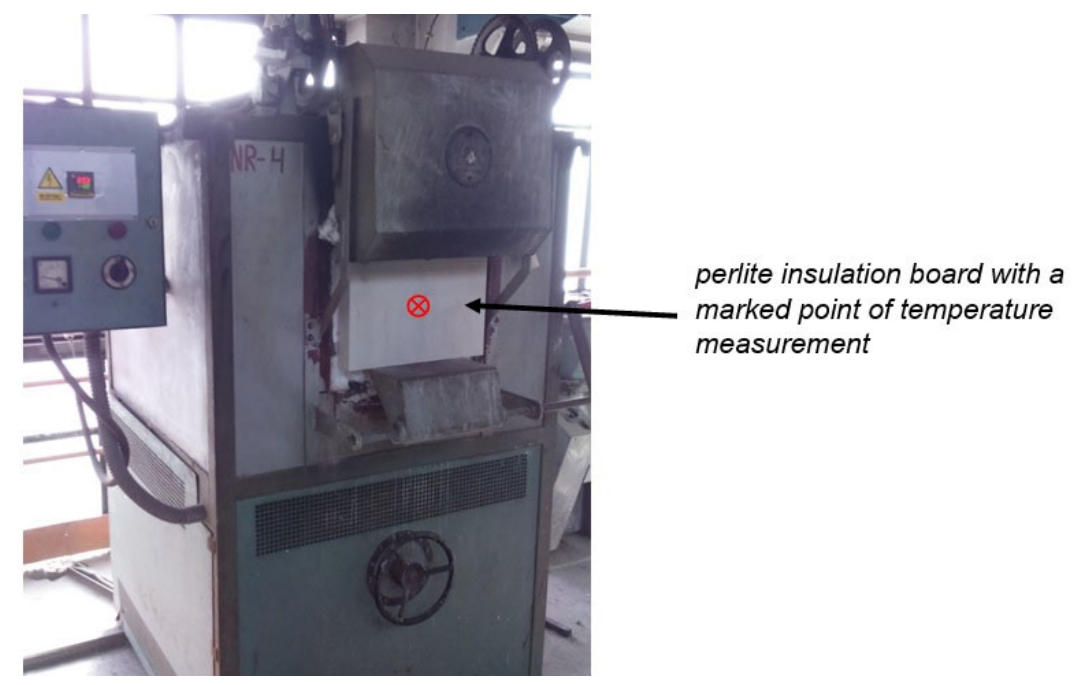

Figure 2. Test stand for determining fire resistance with a board mounted in place of the kiln door

Fire resistance tests were carried out at a special test stand, which allowed simulating the parameters of model temperature curves in the kiln chamber (based on PN-90/B-02851 standard Method of testing the fire resistance rating of building elements), according to the curves of cellulosic or hydrocarbon fire temperature increase. The test stand was equipped with a silit kiln (Figure 2), which was pre-heated to a sufficiently high temperature, i.e. $650{ }^{\circ} \mathrm{C}$ in the case of cellulosic fire simulation, or $950^{\circ} \mathrm{C}$ - in the case of hydrocarbon fire simulation. When the required temperature in the kiln was reached, the kiln door was opened and the tested perlite board was mounted in its place; next, the kiln was further heated to $1100^{\circ} \mathrm{C}$. The measurement time was calculated from that moment. During the determination, the temperature in the kiln was recorded, as well as the time after which temperature on the external side of the sample (not having direct contact with the inside of the heated kiln) reached the limit value, i.e. a temperature increase by $140{ }^{\circ} \mathrm{C}$ in relation to ambient temperature.

In the case of hydrocarbon fire simulation, after reaching the limit value of temperature increase, the measurement was stopped, while in the case of cellulosic fire simulation, the tests were continued until the kiln temperature reached $1100^{\circ} \mathrm{C}$. It was aimed at determining the perlite material's behaviour under the influence of a relatively long contact with high temperature (fire). Temperature on the unheated surface of the perlite product was measured by means of a Raynger PM optical pyrometer, produced by Raytek, with the emission factor of 0.80 . The measurement temperature was taken at the central point of the board (Figure 2).

\section{Results and discussion}

The results of investigations into the physical properties of perlite boards have been presented in Table 2 and in Figure 3. As it can be noticed, perlite boards obtained with binders A, B, C and D are light and have similar volumetric and apparent density. The values of this parameter reach a level of ca $0.28 \pm 0.05 \mathrm{~g} / \mathrm{cm}^{3}$. Undoubtedly, this is an advantage of boards made according to the four developed technological variants.

In terms of insulating properties, the best was the variant with binder $\mathrm{D}$, for which thermal conductivity coefficient was the lowest (below $0.1 \mathrm{~W} /(\mathrm{mK})$ ) - it increased steadily for the remaining binder variants. The best variant with regard to compressive strength was the one with binder $\mathrm{A}$; it is worth noting that the value of this parameter drops for 
variants B, C and D. Due to the high-porous structure, the tested boards are characterized by high absorbability, which is the lowest in the case of boards with binder $\mathrm{A}$.

Observations of perlite sample cross-sections revealed the interesting microstructure of the products (Figure 3), typical of expanded perlite grains. One can see characteristic grains with oval voids, formed in the process of raw perlite expanding, as a result of expansion of water steam trapped in the raw material. The introduction of various types of binders did not affect on the microstructure of the expanded perlite boards. Observed fractures of the all analyzed samples look very similar.

The results of fire resistance measurements have been presented in a graphic form as a correlation between the board surface external temperature and the temperature inside the kiln versus time of the measurement taken under conditions simulating a cellulosic (Figure 4) or hydrocarbon fire (Figure 5). The obtained results have been given in Table 3. Photographs of the macroscopic appearance of materials after tests simulating cellulosic and hydrocarbon fires have been given in Table 4 and a comparison of board cross-sections after tests have been presented in Figure 6. The photographs show fragments cut out from the boards' central area, close to the point of temperature measurement (Figure 2).

Table 2. Main physical properties of perlite board sample

\begin{tabular}{|l|c|c|c|c|}
\hline \multirow{2}{*}{ Property } & \multicolumn{4}{c|}{ Type of perlite board } \\
\cline { 2 - 5 } & $\mathrm{A}$ & $\mathrm{B}$ & $\mathrm{C}$ & $\mathrm{D}$ \\
\hline $\begin{array}{l}\text { Molar content of alkaline substances in binder } \\
\text { calculated on 1000 g of binder }\end{array}$ & 1.0 & 0.6 & 0.4 & 0.2 \\
\hline Bulk density; $\mathrm{g} / \mathrm{cm}^{3}$ & & & & 0.25 \\
\hline Apparent density; $\mathrm{g} / \mathrm{cm}^{3}$ & 0.31 & 0.31 & 0.26 & 0.24 \\
\hline Open porosity; $\%$ & 0.33 & 0.30 & 0.27 & 87.8 \\
\hline Water absorbability; $\%$ & 80.9 & 83.7 & 84.3 & 375 \\
\hline Compressive strength; $\mathrm{MPa}$ & 249 & 283 & 311 & 0.4 \\
\hline \multicolumn{2}{|c|}{ Thermal conductivity $\lambda ; \mathrm{W} /(\mathrm{mK})$} & 0.8 & 0.085 \\
\hline At $150{ }^{\circ} \mathrm{C}$ & 0.109 & 0.107 & 0.115 & 0.093 \\
\hline
\end{tabular}

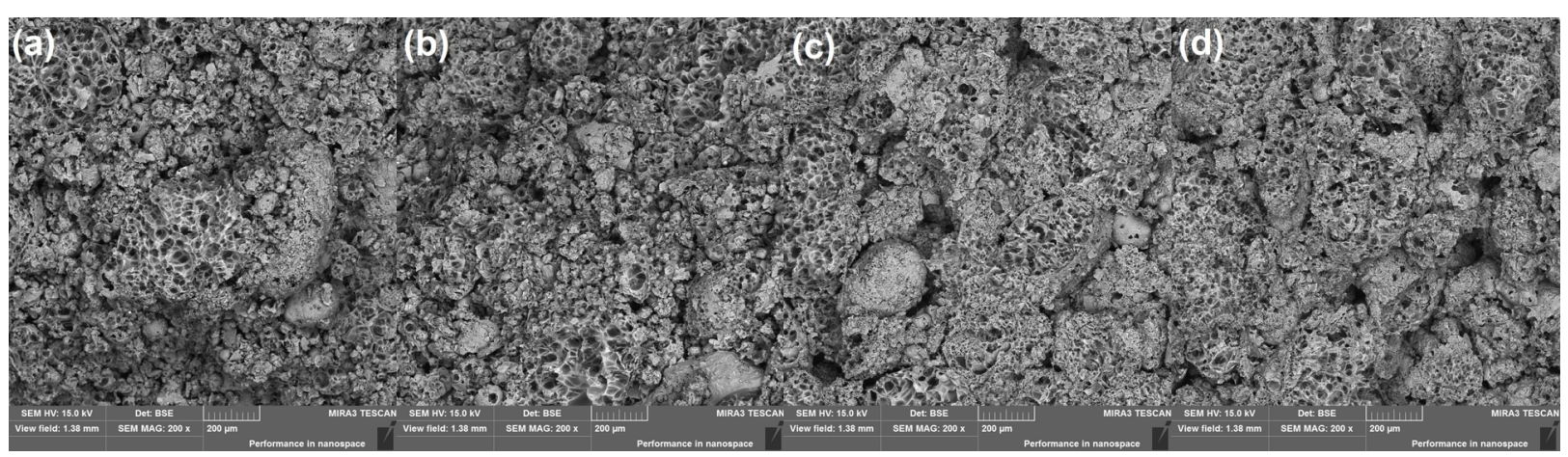

Figure 3. SEM images of the tested perlite board fracture: sample A (a), sample B (b), sample C (c), sample D (d)

Table 3. Time of limit temperature increase on the unheated surface of perlite boards

\begin{tabular}{|c|c|c|}
\hline \multirow{2}{*}{ Sample } & \multicolumn{2}{|c|}{ Time of temperature increase by $140^{\circ} \mathrm{C}$ in the measurement point on the board external surface; min } \\
\cline { 2 - 3 } & cellulosic fire & hydrocarbon fire \\
\hline A & 54 & 22 \\
\hline B & 70 & 24 \\
\hline C & 85 & 24 \\
\hline D & 98 & 30 \\
\hline
\end{tabular}

In respect of model fire curves, it should be emphasized that the mapping of temperature curves in laboratory conditions is quite good. In the case of cellulosic fire, the temperature increase curve coincides with the model one, and in the case of hydrocarbon curve mapping, in the initial period, up to 20 minutes of measurement, it exceeds the 
model conditions. Based on the obtained results, it can be demonstrated that the binder used has an influence on the fire insulation of expanded perlite products, in particular under cellulosic fire conditions - the most frequent fire in man's environment. In this case the shortest time of protection was observed for the board obtained with binder A ca 50 minutes. A nearly twice as long time (ca 100 minutes) was noted for the board obtained with binder D.

On the other hand, in the case of hydrogen fire simulation, due to the boards' very fast contact with a hot atmosphere, fire insulation was much lower (ca 20 $\div 30$ minutes), and differences between the binders used were not so visible. However, in the case of board D, a relatively longest time of protection was achieved. It should be emphasized that the hydrocarbon fire course was modelled under much more drastic conditions than the model curve (Figure 4); it can, therefore, be expected that the time of fire insulation of the considered boards will be slightly longer in this kind of fire.

During measurements, the investigated boards were not affected in a noticeable way - no cracks, smoke emission or hot droplets were observed on the cold side. However, there were visible differences on the hot side, after the boards were dismantled (Table 4). In the case of three samples after the cellulosic fire simulation (boards A, B and C), the surface was visibly glazed. On the other hand, board D retained its porous structure. The greatest glazing was noted in the variant with binder A (board A). Moreover, during this trial, there must have been emissions of volatile/gaseous substances as characteristic porosity was observed to appear, which was particularly visible on the board's cross-section (Figure 5) and in the case of hydrocarbon fire modelling.

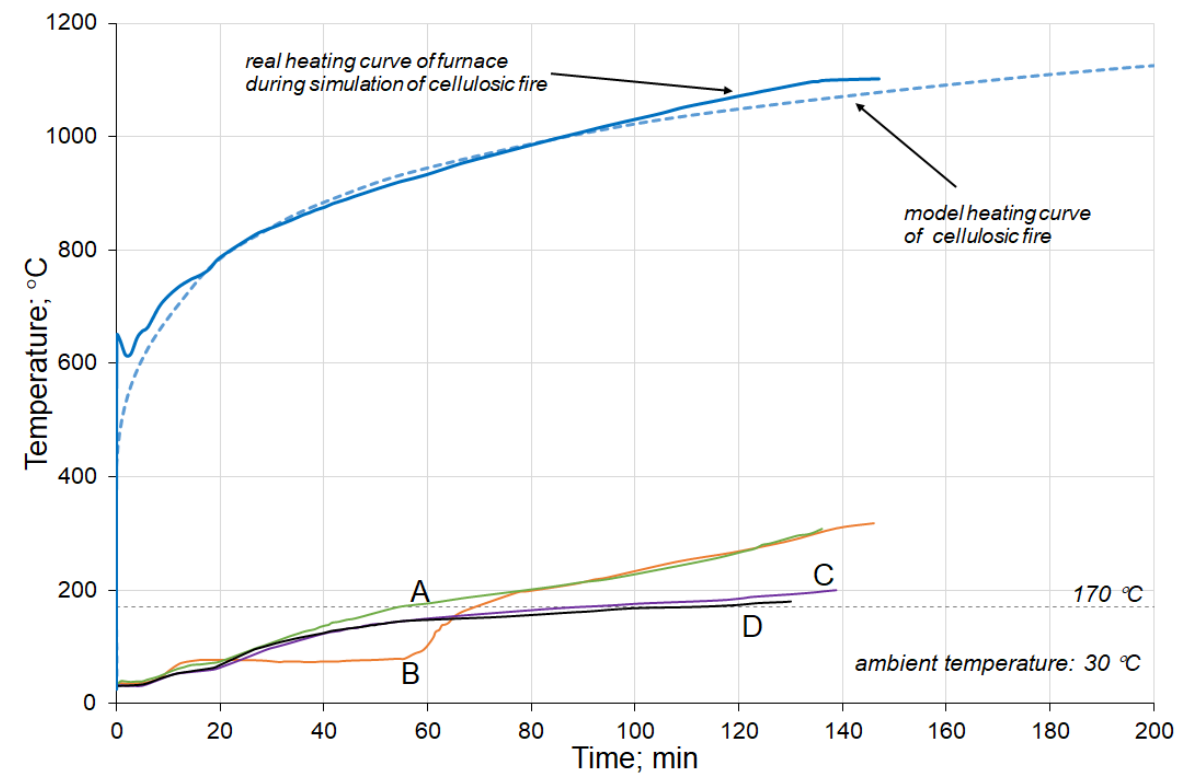

Figure 4. Curves of thermal insulation in relation to cellulosic fire

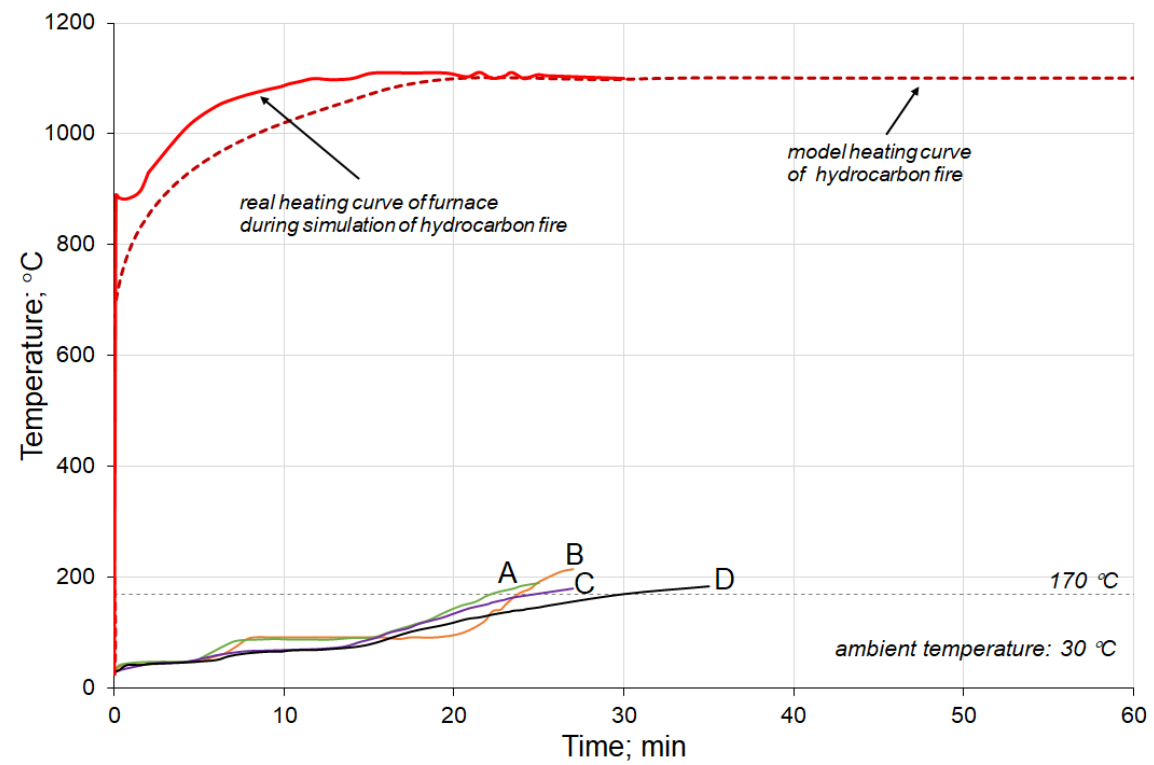

Figure 5. Curves of thermal insulation in relation to hydrocarbon fire 
Another important observation is also a change of the board's thickness after the test. In the case of the board obtained with binder D, there was practically no change in board thickness after measurements (Figure 6), both after the cellulosic and hydrocarbon fire test, the thickness of the board was still ca $50 \mathrm{~mm}$. A slightly smaller thickness was noted in the case of the board obtained with binder $\mathrm{C}$ ( $\mathrm{ca} 45 \mathrm{~mm}$ ). The thickness of boards obtained with binders $\mathrm{A}$ and B gradually decreased with the time of measurement, to finally reach $20 \div 30 \mathrm{~mm}$. It is also noteworthy that board A behaved in a slightly different way - after the test, on the fire side there was a visible "bulge" in the melting board. In case of a flashover, this will probably promote the formation of hot drops in real conditions.

The very change of the course of the recorded temperature increase curve (Figures 4 and 5), also provides important information. It should be noted that for each measurement, the temperature was observed to gradually increase to ca $100{ }^{\circ} \mathrm{C}$; then, for some time it remained constant on the cold side. This effect is the most visible in the case of the board obtained with binder B, under conditions simulating both the cellulosic and hydrocarbon fire. A similar "plateau" effect was also observed by other authors during investigations into vermiculite products (Kozłowski, Mieleniak, Przepiera, \& Bujnowicz, 2004; Kozłowski, Mieleniak, Przepiera, \& Bujnowicz, 2008). A possible explanation for such characteristic behaviour could be absorption of thermal energy by the material and the commencement of the melting process.

Table 4. Macroscopic view of perlite boards from the high-temperature zone after a fire test

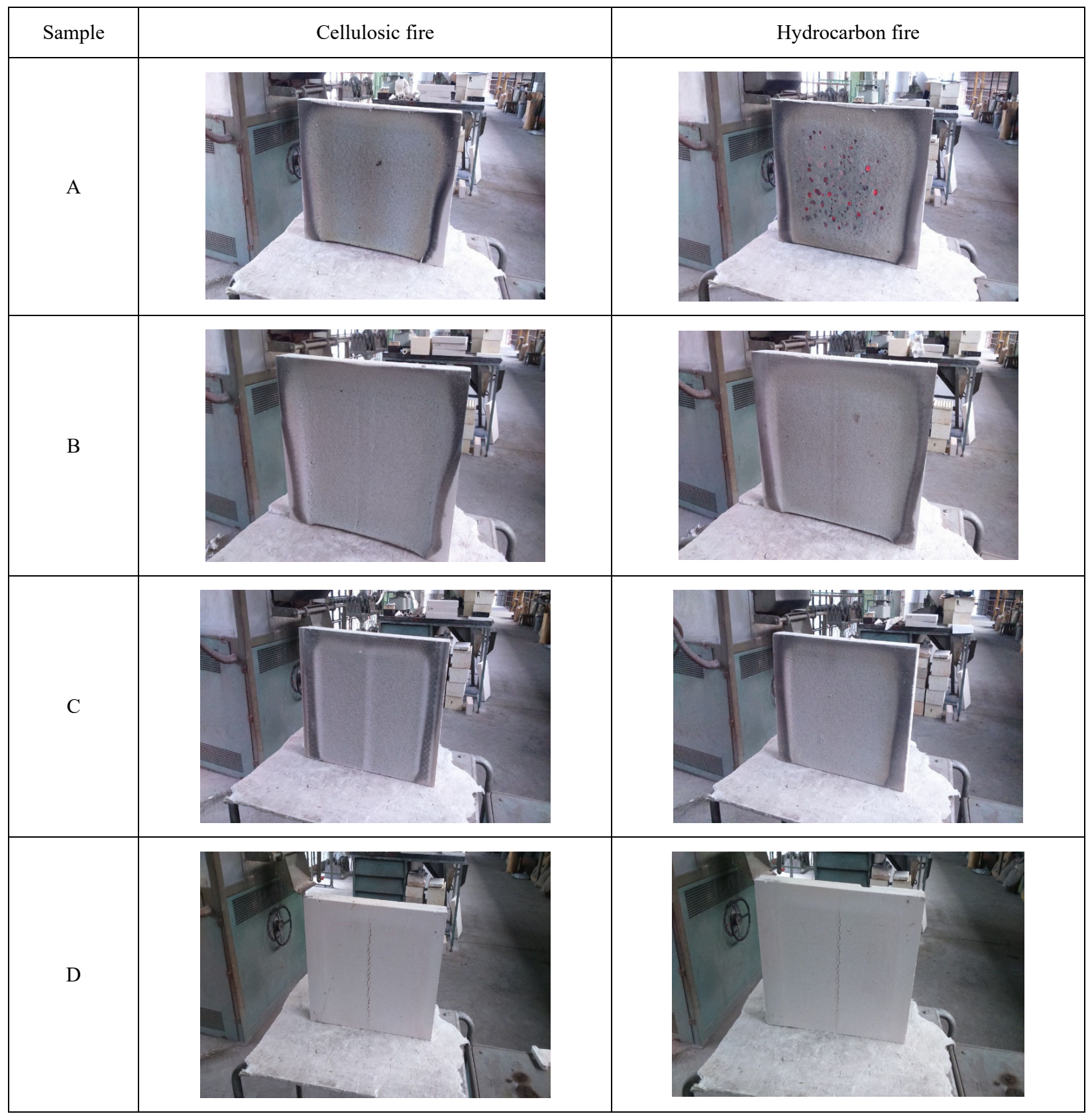




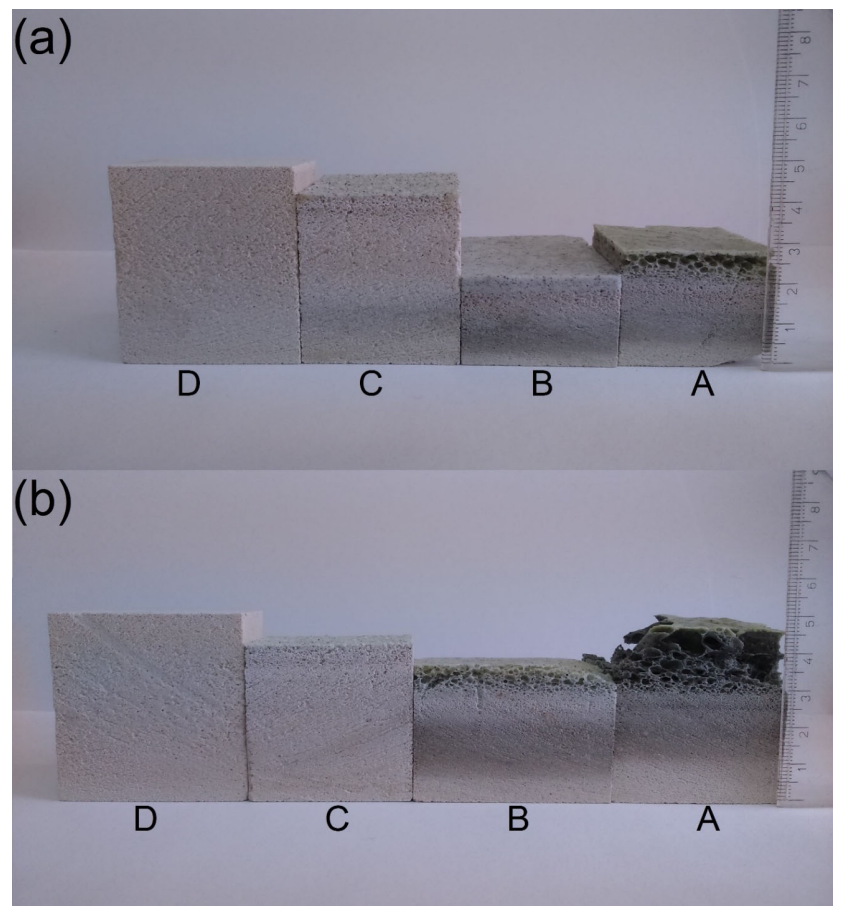

Figure 6. Comparison of sample cross-sections after tests under conditions of (a) cellulosic fire;

(b) hydrocarbon fire (top of the samples - hot zone; original thickness of boards: $50 \mathrm{~mm}$ )

\section{Conclusions}

The results of the conducted investigations allow formulating the following conclusions:

- boards manufactured from expanded perlite and liquid mineral binders are light materials with bulk density $0.25-0.31 \mathrm{~g} / \mathrm{cm}^{3}$, characterized also by good thermal insulation because thermal conductivity was at level from 0.085 to $0.107 \mathrm{~W} / \mathrm{mK}$;

- in the perlite boards manufacturing technology, four variants of binders with differentiated molar content of alkaline substances were used, what allowed to obtain boards with different physical properties and also fire resistance;

- the best insulating and fire resistance properties were obtained in the case of perlite boards bound by a binder with the lowest content of alkaline substances, for which the thermal conductivity coefficient $\chi$ was the lowest and fire resistance under cellulose fire conditions was 98 minutes;

- the best in terms of strength properties was the board variant obtained for binder with the highest content of alkaline substances, for which the compressive strength was $1 \mathrm{MPa}$;

- physical properties and fire resistance of perlite products can be modelled and shaped with respect to specific applications, taking into consideration also the economic aspect;

- the developed perlite boards have also positive fire resistance verification on a larger scale and currently the certification activities for assigning the National Technical Assessment of fire protection systems based on the mentioned above perlite boards is in progress.

\section{Acknowledgements}

The work was carried out as part of a project within the framework of I Priority Axis of the Smart Growth Operational Programme 2014-2020, co-financed from the resources of the European Regional Development Fund: Support for R\&D works carried out by companies. Action 1.1. R\&D projects of enterprises. Submeasure 1.1.1: Industrial research and development works performed by enterprises (so-called „fast track”).

\section{References}

Borowy, A. (2013). Fire resistance testing of building partitions and window joinery (in Polish). http://www.inzynierbudownictwa.pl/dodatki_specjalne,systemy_przeciwpozarowe,artykul,badania_odpornosci_ogniowej_w ewnetrznych_przegrod_budowlanych_oraz_stolarki_otworowej,6964 (4.02.2019)

Burkowicz, A. (2016). Expanded perlite - a thermal insulating material - little-known in Poland. The Bulletin of the Mineral and Energy Economy Research Institute of the Polish Academy of Sciences, 96, 7-22. 
Demirboğa, R., \& Gül, R. (2003). The effects of expanded perlite aggregate, silica fume and fly ash on the thermal conductivity of lightweight concrete. Cement and Concrete Research, 33(5), 723-727. https://doi.org/10.1016/S0008-8846(02)01032-3

Gardelle, B., Duquesne, S., Vandereecken, P., \& Bourbigot, S. (2014). Resistance to fire of silicone-based coatings: Fire protection of steel against cellulosic fire. Journal of Fire Sciences, 32(4), 374-387. https://doi.org/10.1177/0734904114522390

Ghassabzadeh, H., Mohadespour, A., Torab-Mostaedi, M., Zaheri, P., Maragheh, M. G., \& Taheri, H. (2010). Adsorption of Ag, $\mathrm{Cu}$ and $\mathrm{Hg}$ from aqueous solutions using expanded perlite. Journal of Hazardous Materials, 177(1-3), 950-955. https://doi.org/10.1016/j.jhazmat.2010.01.010

Kozłowski, R., Bujnowicz, K., Mieleniak, B., \& Przepiera, A. (2004). Fire barier composites based on vermiculite. Composites, 4 , 331-336.

Kozłowski, R., Mieleniak, B., Przepiera, A., \& Bujnowicz, K. (2008). Vermiculite composite boards as fire barriers. Chemical Industry, 87, 1188-1191.

Markoska, V., Lisichkov, K., Boev, B., \& Gulaboski, R. (2018). The influence of the perlite as a substrate for improving on some water properties on the fluvial soil with an aplication of retentional curves. Journal of Agriculture and Plant Science, 16, 7382.

Sari, A., Tuzen, M., Citak, D., \& Soylak, M. (2007). Adsorption characteristics of $\mathrm{Cu}(\mathrm{II})$ and $\mathrm{Pb}(\mathrm{II})$ onto expanded perlite from aqueous solution. Journal of Hazardous Materials, 148(1-2), 387-394. https://doi.org/10.1016/j.jhazmat.2007.02.052

Sengul, O., Azizi, S., Karaosmanoglu, F., \& Ali Tassemir, M. (2011). Effect of expanded perlite on the mechanical properties and thermal conductivity o lightweight concrete. Energy and Buildings, 43(2-3), 671-676. https://doi.org/10.1016/j.enbuild.2010.11.008

Singh, M., \& Garg, M. (1991). Perlite-based building materials - a review of current applications. Construction and Building Materials, 5(2), 75-81. https://doi.org/10.1016/0950-0618(91)90004-5

Wiatr, J. (2012). Fire temperature effect on value of input voltage powering electrical equipment and the effectiveness of safety protection of equipment required. Informatics Control Measurement in Economy and Environmental Protection, 2, 37-44.

Żelazowska, E., Pichniarczyk, P., \& Najduchowska, M. (2014). Light weight glass-ceramic aggregates for building industry. Ceramic Materials, 66(3), 321-330. 